\title{
MICROSCOPIC ANALYSIS OF THE UTERINE ENDOMETRIUM IN POSTPARTURIENT EWES
}

\author{
M. KRAJNIČÁKOVÁ, E. BEKEOVÁ, L. LENHARDT*, V. CIGÁNKOVÁ*, \\ I. VALOCKY*, I. MARAČEK
}

Research Institute of Experimental Veterinary Medicine, Košice, and University of Veterinary Medicine, Košice, Slovak Republic

Received July 7, 1998

Accepted January 14, 1999

\begin{abstract}
Krajničáková M., E. Bekeová, L. Lenhardt, V. Cigánková, I. Valocký, I. Maraček: Microscopic Analysis of the Uterine Endometrium in Postparturient Ewes. Acta Vet. Brno 1999, 68: 9-12.

Earlier we found that the puerperal period of ewes lambing in February was finished by day 34 post partum. The aim of this paper was to study the puerperal changes in ewes that lambed in September.

Structural changes in the endometrium of the caruncular region were studied in 12 Slovak Merino ewes that lambed in September. The animals were killed on days 7, 17, 25 and 34 post partum. Samples were taken from the caruncular region of their uterine horns. The tissue samples were fixed, dehydrated and embedded in paraffin, and 7-10 $\mathrm{mm}$ sections were stained with hematoxylin-eosin. Microscopic analysis was performed using a projection microscope. Simultaneously the collected material was stained with toluidine-blue, and examined on the semi-thin sections. The epithelium above the caruncles was entirely destroyed on day 7 . Damaged mitochondria and dilated cisterns of the endoplasmic reticulum were found in the electron micrographs. On day 17, the epithelium covered gradually a sizeable caruncle. The glandular epithelium was considerably degenerated. The caruncle was markedly reduced on day 25 , and the endometrium was covered with epithelium. The endometrium was totally covered with epithelium, and cellular ultrastructure was no more damaged on day 34 post partum. The study of micromorphology of endometrial structure in caruncular area revealed that also in ewes that lambed in September, the puerperium is finished by day 34 post partum. Its course and timing did not differ from that seen in ewes lambing in February. The results extend the knowledge of the puerperal changes in different season of the year.
\end{abstract}

Caruncular region, endometrium, ewe, histological structures, post partum, season of the year

One of the factors that may unfavourably affect fertility is the course of the involutional and reparatory processes of the uterus in the postpartal period. At the onset of postpartal reproductive activity it is necessary to take into account the breed, the season of the year, nutrition, and the length of suckling (Kudláč 1985; Doležel 1989).

The macroscopic changes occurring during involution of the sheep uterus were reported by Foote and Call (1969); Crowder et al. (1982); Botha (1976); Van Wyk et al. (1972); Krajničáková (1990); Greyling and Van Niekerk (1991) in goat, and Massányi (1996) in rabbits. A comprehensive histological study of the sheep uterus post partum was carried out by Uren (1935); and Van Wyk et al. (1972) who found that the involution process of the uterus was completed by day 28 post partum. Botha (1976) reported that both the season and lactation influence epithelisation of the caruncles. The author observed sheep that lambed during the out-of-mating season (August) to have epithelisation in the caruncular region finished on day 34 post partum whereas those that lambed in the lambing season (March) on day 30 post partum.

Address for correspondence:

MVDr. M. Krajničáková, CSc.

MVDr. M. Krajničáková, CSc.
Research Institute of Experimental Veterinary Medicine,
Hlinkova 1/A

04001 Košice, Slovak Republic
Phone: +421-95-6332011, klp. 221

Fax: +421-95-6331853

E-mail: vuvm@vuv 
In our conditions, uterine involution in Slovak Merino sheep lambed in February was found to be finished by day 34 post partum Krajničáková et al. (1994). The aim of this study was to obtain data on the course of histological changes in the endometrial structures and entire covering of caruncles with epithelium after autumn lambing of sheep of the same breed kept in our conditions.

\section{Materials and Methods}

Twelve Slovak Merino ewes were included in the experiment. The animals, weighing about 40-50 kg, and 3-5year-old, were kept on a commercial farm. We observed a physiological course of delivery in all animals including departing of placenta. Puerperium in all the ewes proceeded without any complications. The animals $(\mathrm{n}=12)$ lambed in September. They were on pasture and were housed 3 weeks before parturition. The ewes were fed meadow hay, fodder beet, maize silage, feed mixture BAK and concentrates. Feed mixture BAK is composed of extracted flax meal, wheat flour, wheat bran, malt flour, wheat meal, barley, salt, mineral additive III, and biofactor additive. Water and salt were given ad libitum. The ewes were killed $(\mathrm{n}=3)$ on days 7, 17, 25 and 34 post partum. Immediately after lambing, the reproductive apparatus was excised and samples were taken from the caruncular region. Samples were fixed in $10 \%$ formalin. The samples were dehydrated and embedded in paraffin, and 7-10 $\mu \mathrm{m}$ thin sections were stained with hematoxylin-eosin. The sections were observed using projection microscope. One $\mathrm{mm}^{3}$ thin sections for analysis in the electron microscope were fixed for $3 \mathrm{~h}$ by immersion in $3 \%$ glutaraldehyde and subsequently for $1 \mathrm{~h}$ in $2 \%$ osmium oxide in phosphate solution $(\mathrm{pH} 7.4)$; then they were gradually dehydrated in increasing series of alcohol, rinsed in propylene oxide and embedded into Durcupan ACM (Fluka). Semi-thin sections were stained with toluidine blue and examined in the electron microscope JEM 1200 Ex. The electron micrographs were made by the projection microscope Olympus $\mathrm{CH} 2$ with a camera.

\section{Results}

Endometrial histological structure in the caruncular region of sheep lambed in September is presented in Figures 1 to 8 (Plates II-V). Fig. 1 shows the uterine sample of a sheep on day 7 post partum; the epithelium above the caruncle was entirely destroyed. Caruncles had large spaces without glands, sharply demarcated from the glandular part of the endometrium. Branches of the uterine artery were slightly dilated and filled with erythrocytes. In the glandular part of the endometrium, the volume of some glands was enlarged and the lumen of secretory parts was dilated. In the endometrial tunica propria, which was rich in cells, fibrocytes, migratory cells and reticular fibres prevailed. In the electron micrograph (Fig. 2), there were microvilli (mv) on the apical surface of cells. Damaged mitochondria (m) and dilated cisterns of the endoplasmic reticulum (er) were in the cytoplasm.

On day 17 (Plate III, Fig. 3) post partum, the epithelium of the endometrium occurred, gradually covering a relatively sizeable caruncle. A multi-layered cylindrical epithelium in some parts changed into an one-layered flat one. The uterine glands were subject to gradual regression and only a small number of them had still apparently dilated lumen of secretory parts. Fig. 4 shows degenerated glandular epithelium, cells were marked with nuclear pyknosis, disintegration of cells and their release into the glandular lumen. Clean-cut subepithelial cumulation of fatty cells $(\mathrm{mc})$, macrophages and sporadic lymphocytes occurred in the endometrium (Plate IV, Fig. 5).

On day 25 (Fig. 6) after lambing, the endometrium in the caruncular region was covered with epithelium. The caruncle was markedly reduced compared to day 17 , and from the glandular part of endometrium it was sharply demarcated by a band of reticular fibres. Numerous uterine glands, whose lumen was markedly reduced, occurred in the lamina propria.

On day 34 post partum (Plate V, Fig. 7) the endometrial mucosa was intact. The endometrium was entirely covered with epithelium. Spaces without glands formed a narrow band that was localised close under the basal membrane of the mucosa. The electron micrograph (Fig. 8) shows a part of epithelial surface of the uterine endometrium, where numerous microvilli (mv) occurred on the apical surface. The cellular ultrastructure was undamaged. Numerous secretory granules (sg) occurred in the cytoplasm. 


\section{Discussion}

Evaluation of the morphological structure of the endometrium on day 7 post partum revealed that the epithelium in the caruncular region was entirely degenerated. Branches of the uterine artery were dilated and filled with erythrocytes. Our results are similar to those reported by Van Wyk (1972) between days 4 and 12 of the postparturient period in sheep. Similar findings were reported by Greyling and Van Niekerk (1991) in goat post partum. At the observed time interval, damaged mitochondria in the cytoplasm of epithelial cells and dilated cisterns of the endoplasmic reticulum were observed. Uhrín (1992) recorded changes in mitochondria, even their death, by the end of the sexual cycle, when there was also dilation of cisterns of the endoplasmic reticulum. Our findings of the structural changes in these organelles may be connected with gradually progressive proliferation in the postparturient period.

The histological analysis of the results on day 17 post partum indicates progressive process of involution of the uterus. The epithelium of the endometrium gradually covered still large caruncle. The glandular epithelium was considerably degenerated and released cells were present in the lumen. In the endometrium, there were more marked numbers of macrophages and lymphocytes. Regarding the physiological course of involutional and reparatory processes of the uterus, their functionality appears to be inevitable. Results of our observations on the day evaluated are in agreement with the data obtained on day 20 post partum in goat (Greyling and Van Niekerk 1991) and findings of Kudláč (1985)post partum in cows.

Our findings on day 25 post partum indicate more marked proliferation of the superficial epithelium of the endometrium in the caruncular region. In the lamina propria, there are uterine glands with markedly reduced lumen. These findings do not differ from those of the postparturient period of sheep lambed in February (Krajničáková et al. 1994).

On day 34, intact endometrial mucosa was detected in our experimental group. The endometrium was covered with epithelium in the whole extent. The involution process of the uterus in sheep according to V an Wyk et al. (1972) is finished until day 28 post partum. Crowder et al. (1982) found complete uterine involution by day 32 after lambing. Evaluation of the morphological structure of the epithelium of the endometrium of uterus in the caruncular region in our experiment confirms its reparation up to day 34 post partum. This fact is also confirmed by the undamaged structure of cells and numerous microvilli on the cells of luminal epithelium of the endometrium. The histological picture of similar character is reported by Śtastný (1993) in cycling heifers. Graig and Jollie (1984) found that luminal cells of the endometrium in rats react to administration of estrogens by formation of microvilli. Results of Koch et al. (1985) obtained after administration of ovarian steroids to rats are in agreement with these authors. The fact that formation of microvilli is stimulated by estrogens is confirmed also by our findings of concentrations of ovarian hormones in the animals under study (Krajničáková et al. 1996). The presence of numerous secretory granules in the cytoplasm of cells that were found on day 34 post partum, is manifestation of their higher metabolic and secretory activity as reported by Š tastný (1993) in cycling animals.

Our results indicate that in Slovak Merino sheep lambing out of season (September), the involutional process is completed by day 34 after parturition similar to the results found in sheep that lambed in February. Completed covering of the whole endometrial surface, including the protruded margins of caruncles with the epithelium was recorded on day 34 after lambing of our experimental ewes. 


\section{Mikroskopická analýza endometria maternice oviec v popôrodnom období}

Sledovali sme štrukturálne zmeny endometria v karunkulárnej oblasti u 12 oviec plemena slovenské merino. Zvieratá boli odporážané na 7., 17., 25. a 34. deň po pôrode. Vzorky sme odoberali z karunkulárnej oblasti rohov maternice. Po fixácii, odvodnení a zaliatí do parafínu sme 7-10 $\mu \mathrm{m}$ rezy ofarbili hematoxylín-eozínom. Mikroskopickú analýzu sme robili projekčným mikroskopom. Súbežne sme vyšetrovali odobraný materiál na polotenkých rezoch, ktorý sme ofarbili toluidinovou modrou. Pri hodnotení vzoriek zo 7. dňa po pôrode bol epitel nad karunkulom úplne deštruovaný. V elektronograme sme zistili poškodené mitochondrie a dilatované cisterny endoplazmatického retikula. $\mathrm{Na} \mathrm{17}$. deň epitel postupne pokrýval mohutný karunkul. Žlazový epitel bol značne degenerovaný. Karunkul bol na 25. deň výrazne zmenšený a endometrium bolo zakryté povrchovým epitelom. Endometrium bolo úplne zakryté povrchovým epitelom a ultraštruktúra buniek bola neporušená k 34. dňu po pôrode.

\section{References}

BOTHA, H. K. 1976 in VAN NIEKERK, C. H.: Limitations to female reproductive efficiency. In: Sheep breeding. Ed. by Tomes, G. J., Robertson, D. E., Lightfoot, R. J., Butterworts, London 1979, pp. 303-313

CRAIG, S. S., JOLITE, W. P. 1984: The response of uterine surface to ovarian hormones in the aged rat. Anat. Embryol. 169: 205-208

CROWDER, M. E., GILLES, P. A., TAMANINI, C., MOSS, G. E., NETT, T. M. 1982: Pituitary content of gonadotropins and GnRH-receptors in pregnant, post-partum and steroid-treated ovx ewes. J. Anim. Sci. 54: 1235-1242

DOLEŽEL, R. 1989: Dynamika změn vybraných ukazatelů fyziologie puerperia na pohlavním ústrojí a v periférní krvi krav. Thesis, VŠV Brno, $180 \mathrm{p}$.

FOOTE, W. C., CALL, J. W. 1969: Postpartum changes in the uterus and blood of the ewes during the anestrous season. J. Anim. Sci. 29: 190

GREYLING, J. P. C., VAN NIEKERK, C. H. 1991: Involution of the post partum uterus of the Boer goat. J. S. Afr. Vet. Assoc. 62: 4-9

KOCH, M., STRACKE, R., PESCHKE, T. H. 1985: Effects of antifertility estrogens and progestins on the endometrial surface of early pregnant rats. A scanning electron microscopic study. Exp. Clin. Endocrinol. 85: $138-146$

KRAJNIČÁKOVÁ, M., ELEČKO, J., BEKEOVÁ, E., MARAČEK, I., HENDRICHOVSKÝ, V. 1990: Biometrické parametre maternice, vaječníkov a koncentrácia 17-beta estradiolu po pôrode oviec. Vet. Med. Praha 35: 747-750

KRAJNIČÁKOVÁ, M., BEKEOVÁ, E, MARAČEK, I, HENDRICHOVSKY, V., KAČMÁRIK, J. 1994 Micromorphological changes of the endometrium in the postpartum period of ewes. The International Conference on Reproduction of Farm Animals Liptovský Ján, Proceeding Book, pp. 197-200

KRAJNIČÁKOVÁ, M., BEKEOVÁ, E., HENDRICHOVSKY, V., MARAČEK, I. 1996: Ovarian follicular dynamics in sheep during puerperal period. J. Physiol. Pharmacol. 47: 124 (Abstr.)

KUDLÁČ, E. 1985: Látkový metabolismus u krav v peripartálním období a jeho vztah k průběhu puerperia a další plodnosti. Veterinářství 35: 497-498

MASSANYI, P. 1996: Štrukturálne zmeny vaječníka, vajcovodu a maternice samice králika po podaní kadmia. Monografia, VŠP Nitra: $1-70$

ŠŤASTNY, P. 1993: Zmeny štruktúry sliznice vajcovodu a maternice jalovíc v postpartálnom období. Acta Zootechnica, VŠP, Nitra, XLVIII, pp. 1-50

UHRÍN, V. 1992: Funkčná morfológia epitelov vajcovodu a maternice kravy. Monografia. VÚŽV Nitra, 169 p.

UREN, A. W. 1935: Involution of uterine mucosa in the ewes. Technical Bulletin Michigan (State College) Agricultural Experimental Station. 144: 64-72

VAN WYK, L. C., VAN NIEKERK, C. H., BELONJE, P. C. 1972: Involution of the post partum of the ewe. J. S. Afr. Vet. Ass. 43: 19-26 
Plate II

M. Krajničáková et al.: Microscopic... pp.xx

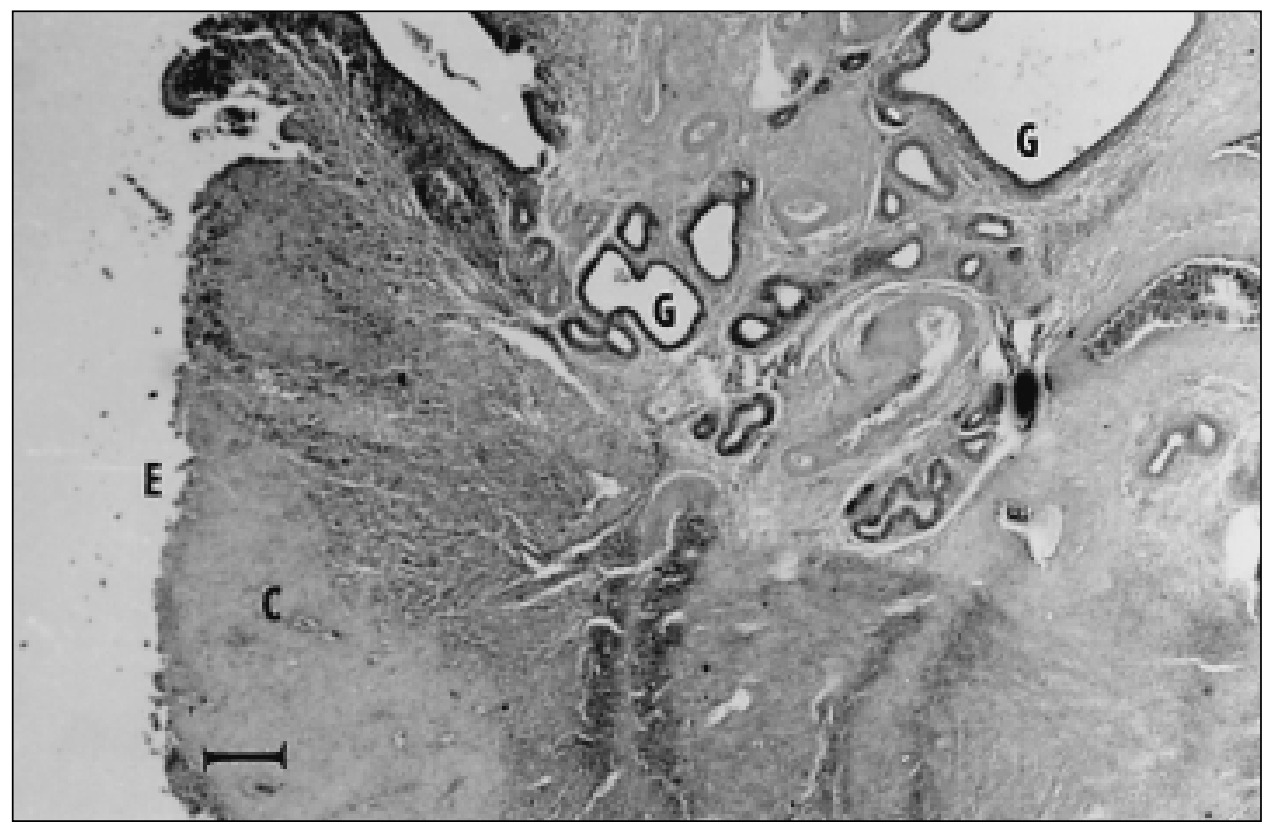

Fig. 1. Caruncular region of the endometrium on day 7 post partum. The epithelium above the caruncle is entirely degenerated. The volume of some glands is enlarged. HE. Bar $=40 \mu \mathrm{m}$

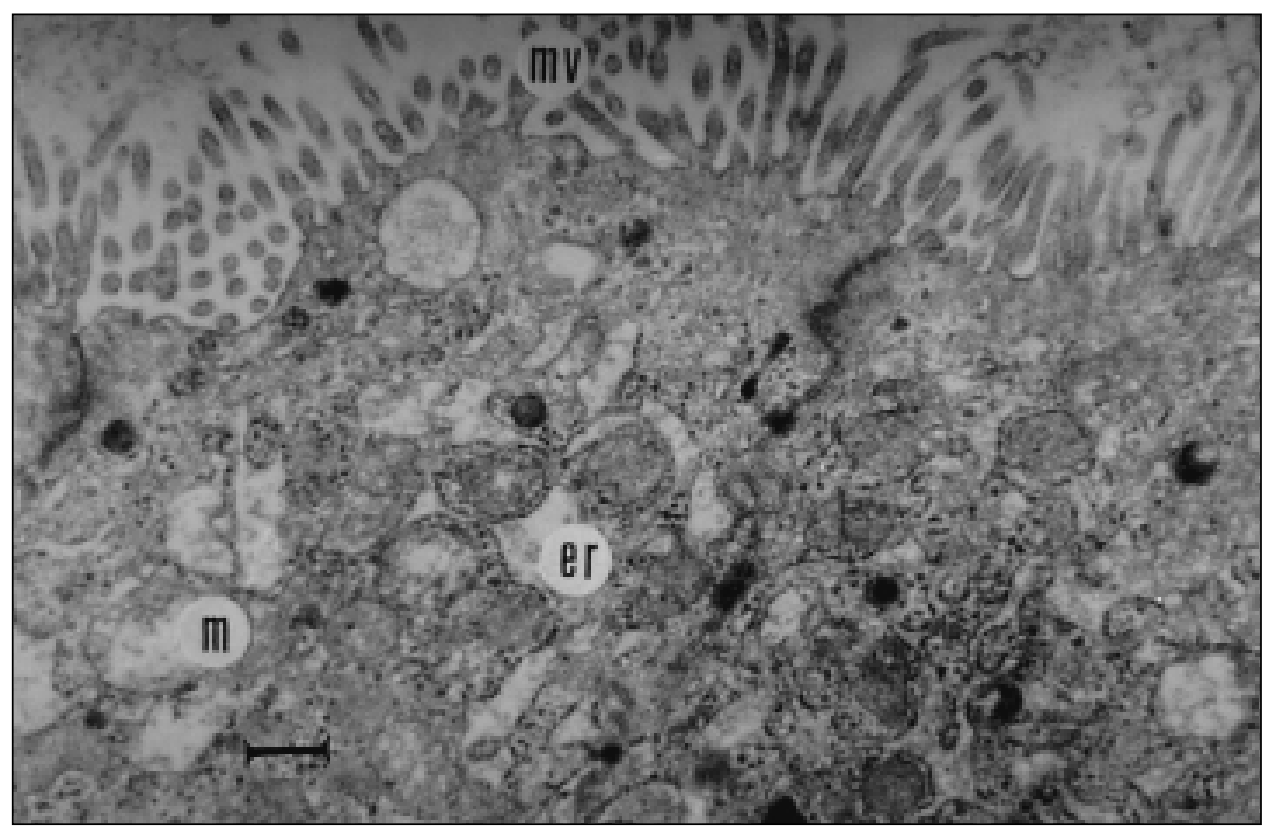

Fig. 2. Electron micrograph of the sheep (day 7 post partum) shows the epithelial cells of the endometrium. Microvilli (mv), mitochondria (m), endoplasmic reticulum (er). Toulidine blue. Bar $=0.5 \mu \mathrm{m}$ 
Plate III

M. Krajničáková et al.: Microscopic... pp.xx

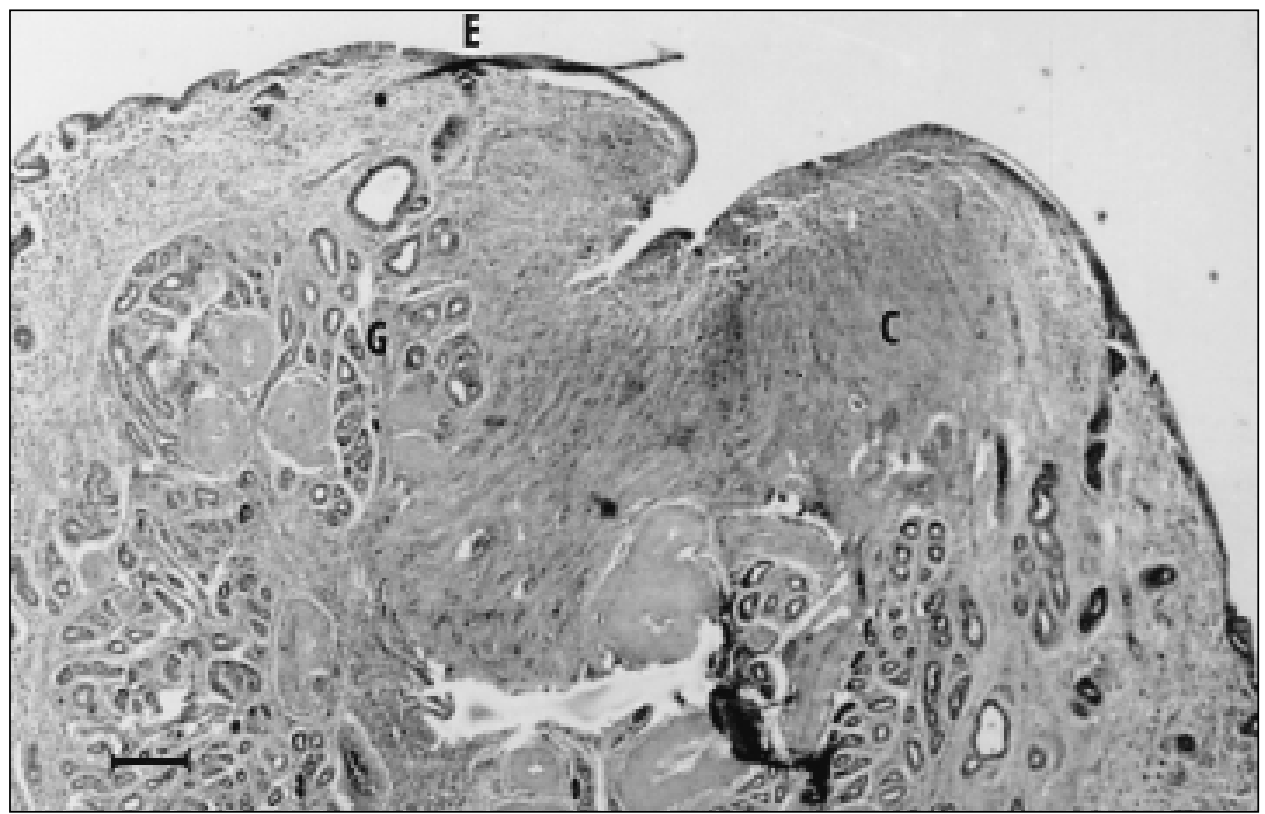

Fig. 3. Superficial epithelium of the endometrium gradually covers still sizeable caruncle. Caruncle (c), epithelium (e), uterine glands (g). HE. Micrograph from day 17 post partum. HE. Bar $=40 \mu \mathrm{m}$

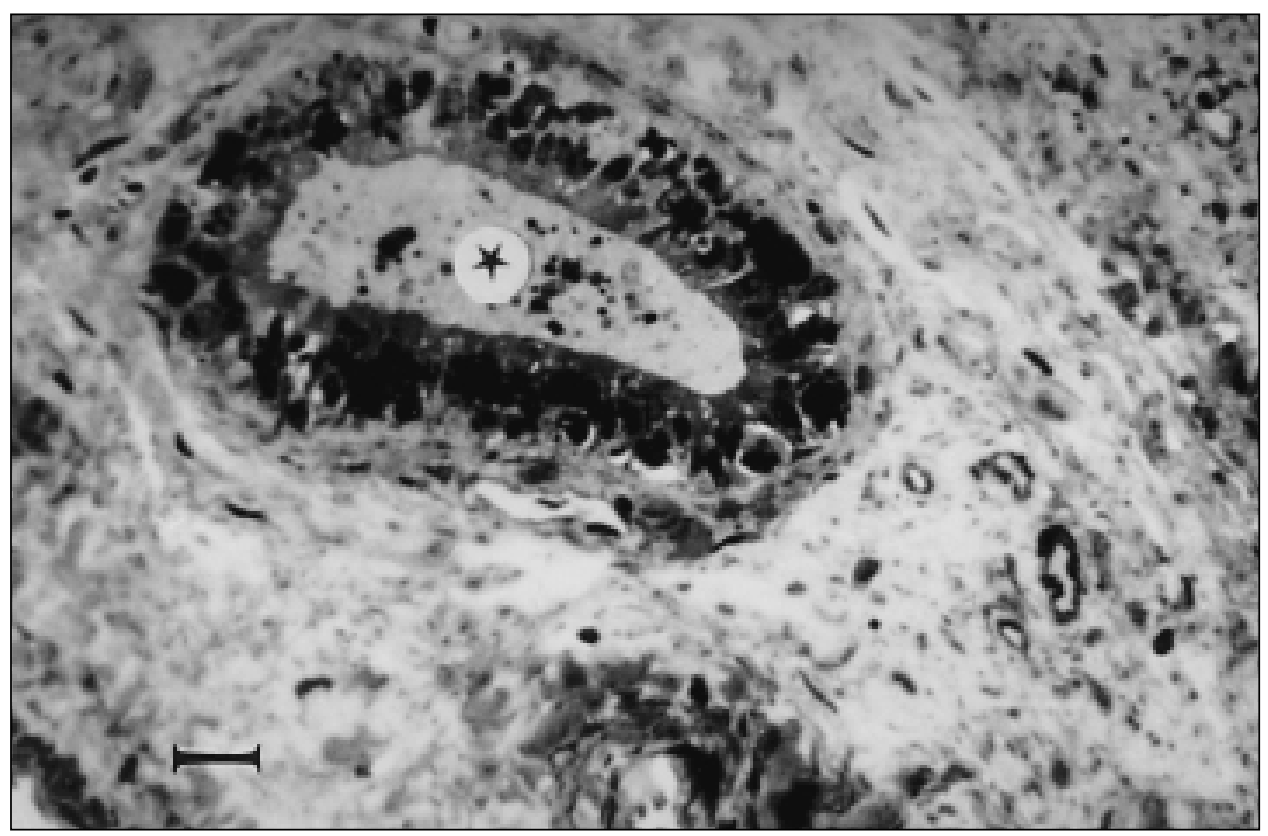

Fig. 4. Cells of the epithelium of endometrial glands are disintegrated and released into the glandular lumen (day 17 post partum). Toluidine blue. $\mathrm{Bar}=10 \mu \mathrm{m}$ 
Plate IV

M. Krajničáková et al.: Microscopic...pp.xx

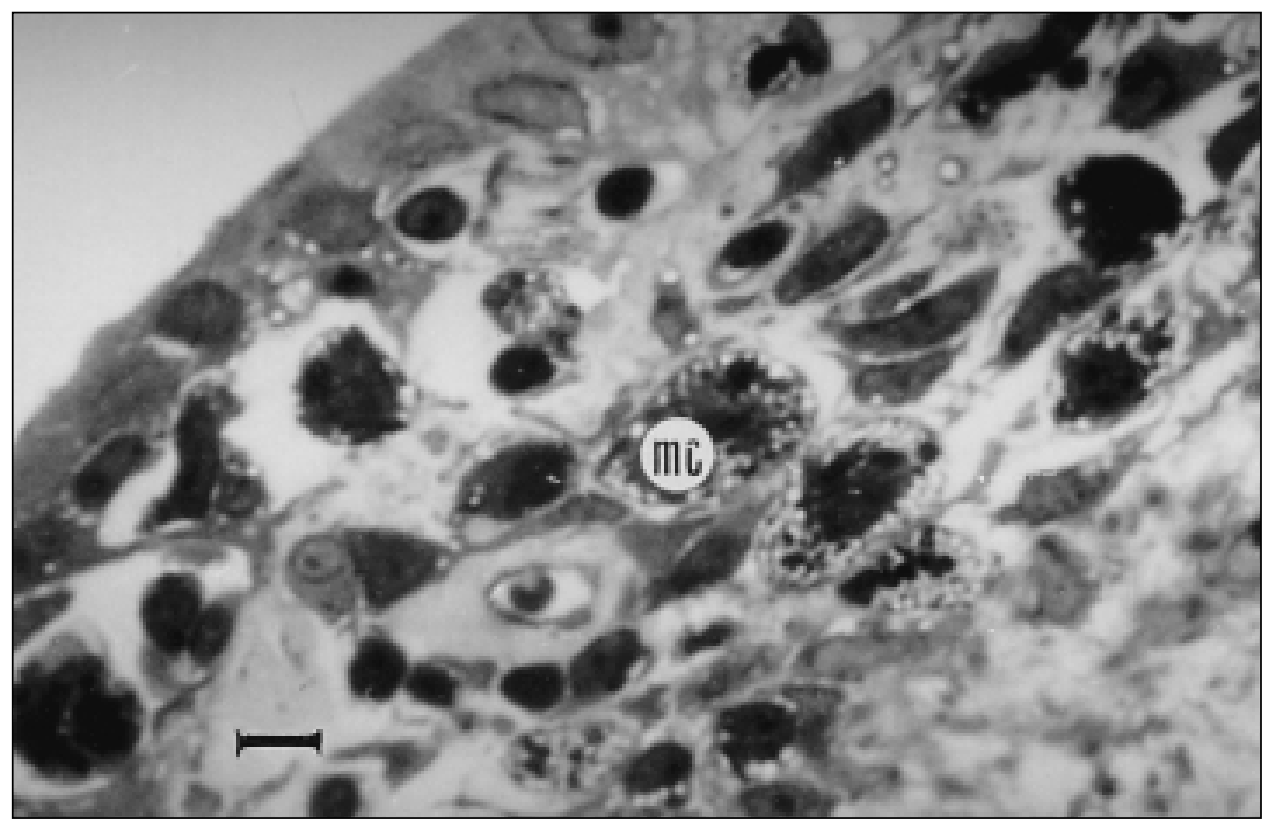

Fig. 5. Electron micrograph (day 17 post partum) depicts the presence of macrophages (mc) and lymphocytes in the superficial epithelium of the endometrium. Toluidine blue. $\mathrm{Bar}=5 \mu \mathrm{m}$

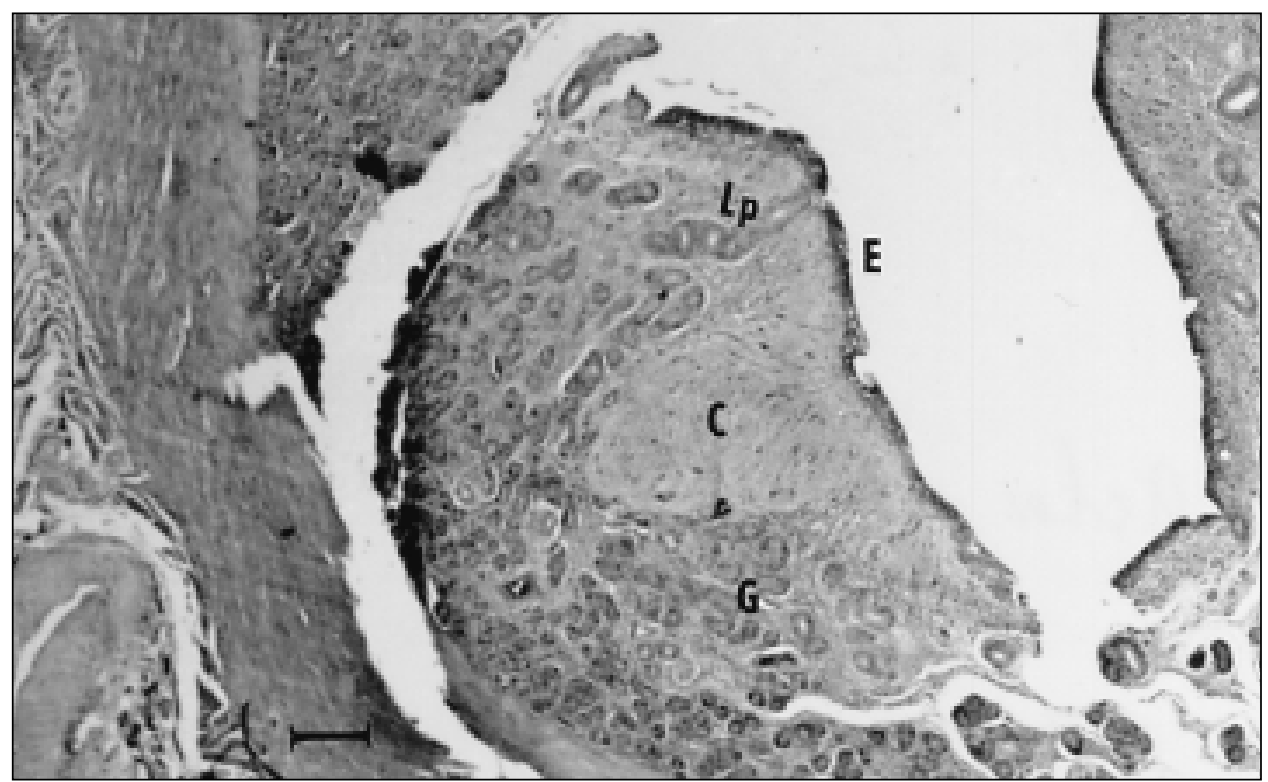

Fig. 6. Micrograph presents the endometrium in the caruncular region (day 25 post partum). Caruncle (c) is reduced and it is demarcated from the glandular part of the endometrium by a band of reticular fibres (r.f.) In the lamina propria (1.p.) uterine glands (g) are visible. HE. Bar $=40 \mu \mathrm{m}$ 
Plate V

M. Krajničáková et al.: Microscopic... pp.xx

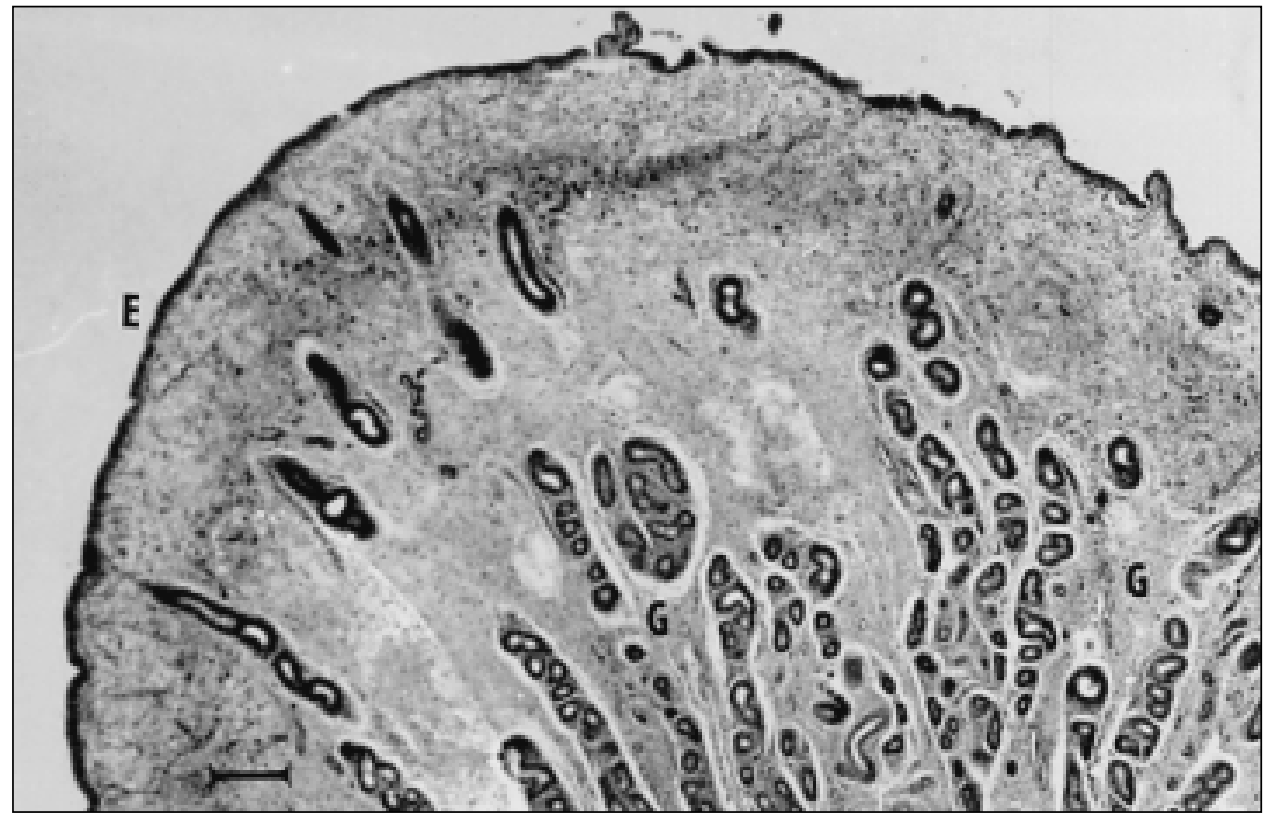

Fig. 7. Superficial epithelium of the endometrium after completing of tissue regeneration in the caruncular region (day 34 post partum). Endometrial epithelium (e). HE. Bar $=40 \mu \mathrm{m}$

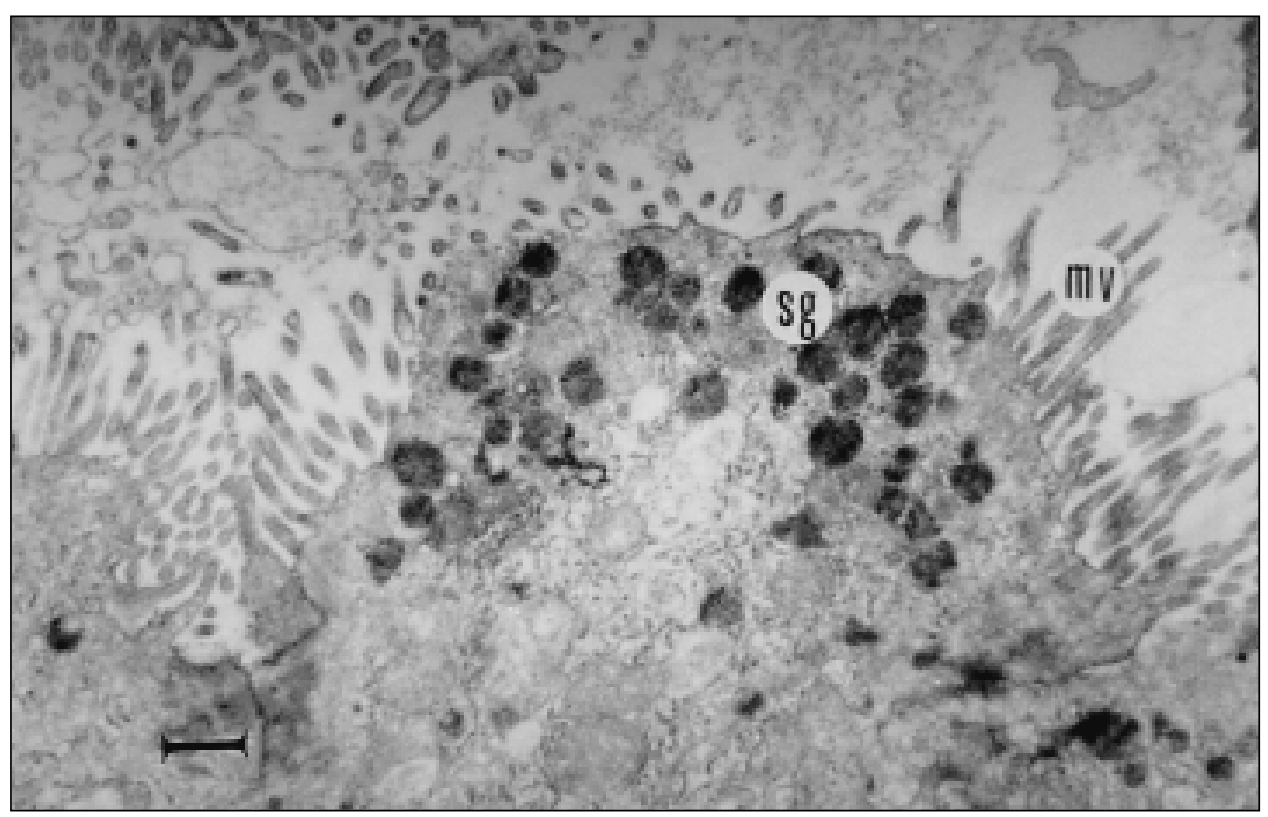

Fig. 8. Electron micrograph shows the undamaged cellular structure of the endometrial epithelium and in the cytoplasm there are secretory granules (sg). There are microvilli (m.v.) on the cell surface. Toluidine blue. Bar $=0.5 \mu \mathrm{m}$ 